\title{
Release of $\boldsymbol{C}$-terminal tyrosine from tubulin and microtubules at steady state
}

\author{
Carlos A. ARCE and Héctor S. BARRA \\ Centro de Investigaciones en Química Biológica de Córdoba (CIQUIBIC), UNC-CONICET, Facultad de \\ Ciencias Quimicas, Casilla de Correo 61, 5016 Córdoba, Argentina
}

(Received 2 October 1984/Accepted 15 October 1984)

\begin{abstract}
Microtubule protein preparations purified by cycles of assembly-disassembly contain the enzyme tubulinyltyrosine carboxypeptidase (TTCPase). Using these preparations, containing tubulinyl[ $\left[{ }^{14} \mathrm{C}\right]$ tyrosine, we studied the release of $\left[{ }^{14} \mathrm{C}\right]$ tyrosine from assembled and non-assembled tubulin under steady-state conditions. It was found that both states of aggregation were detyrosinated at similar rates by the action of the endogenous TTCPase. However, practically no release of $\left[{ }^{14} \mathrm{C}\right]$ tyrosine from the nonassembled tubulin pool was found when microtubules were previously eliminated from the incubation mixture. These results indicated that non-assembled tubulin requires to interact with microtubules to be detyrosinated. This interaction seems to occur through the incorporation of dimers into microtubules, since when the capability of tubulin to incorporate into microtubules was diminished by binding of colchicine a concomitant decrease in the rate of release of tyrosine was observed. When detyrosination was accelerated by increasing the concentration of TTCPase relative to the microtubule protein concentration, microtubules were found to be detyrosinated faster than was non-assembled tubulin. Using exogenous TTCPase in an incubation system in which the formation of microtubules was not allowed, tubulinyl $\left[{ }^{14} \mathrm{C}\right]$ tyrosine and tubulinyl $\left[{ }^{14} \mathrm{C}\right]$ tyrosine-colchicine complex were shown to have similar capabilities to act as substrates for this enzyme. Free colchicine was shown not to affect the activity of TTCPase.
\end{abstract}

The post-translational modification of tubulin which involves the addition or release of a tyrosine residue at the $C$-terminus of the $\alpha$-chain has been previously described (Barra et al., 1974; Arce et al., 1975; Hallak et al., 1977; Raybin \& Flavin, 1977; Argaraña et al., 1980). The product of the incorporation reaction, tubulinyltyrosine, has apparently the same capacity as non-tyrosinated tubulin to assemble into microtubules in vitro (Arce et al., 1978; Kumar \& Flavin, 1982). However, it was reported that in brain tissue from new-born rats the proportion of tyrosinated tubulin in the non-assembled fraction is higher than that in the microtubule fraction (Rodriguez \& Borisy, 1979). It is possible that the ratio tyrosinated/nontyrosinated tubulin in both states of aggregation depends not only on the relative capabilities of

Abbreviations used: TTCPase, tubulinyltyrosine carboxypeptidase; TTLase, tubulin :tyrosine ligase; MTP, microtubule protein. both species of tubulin to assemble into microtubules but also on the relative capabilities of both states of aggregation to act as substrates of the tyrosinating enzyme, tubulin:tyrosine ligase (TTLase) and the detyrosinating enzyme, tubulinyltyrosine carboxypeptidase (TTCPase) (Arce et al., 1978). In a previous work we showed that TTLase incorporates tyrosine into tubulin dimers but not into microtubules (Arce et al., 1978). This was confirmed by Deanin et al. (1980). On the other hand, several authors (Hallak et al., 1977; Thompson, 1977; Deanin et al., 1980; Kumar \& Flavin, 1981) have reported that microtubules are the preferred substrate for the TTCPase. Recently, we have reported that TTCPase associates with microtubules in vitro in such a way that microtubule protein purified by up to five cycles of assembly-disassembly contains TTCPase activity (Arce \& Barra, 1983).

The present work deals with the action of endogenous TTCPase on both assembled and nonassembled tubulin under steady-state conditions. 


\section{Materials and methods}

\section{Materials}

L-[U-14 C]Tyrosine (sp. radioactivity $450 \mu \mathrm{Ci}$ / $\mu \mathrm{mol})$ was obtained from New England Nuclear. Sephadex G-25 (28-80 $\mu \mathrm{m})$, DEAE-Sephadex A50, Pipes, Mes and EGTA were purchased from Sigma. Colchicine was purchased from Merck.

\section{Brain extract preparation}

Brains from 30-60-day-old rats were homogenized in 1 vol. of Pipes buffer ( $0.1 \mathrm{M}$-Pipes adjusted with $\mathrm{KOH}$ to $\mathrm{pH} 6.7$, containing $1 \mathrm{mM}$ EGTA). The homogenate was centrifuged at $100000 \mathrm{~g}$ for $1 \mathrm{~h}$ at $2-4^{\circ} \mathrm{C}$ and the supernatant solution was immediately used.

\section{Preparation of $\left[{ }^{14} \mathrm{C}\right]$ tyrosinated microtubule protein by assembly-disassembly}

For the incorporation of $\left[{ }^{14} \mathrm{C}\right]$ tyrosine into tubulin the incubation mixture contained per $\mathrm{ml}$ : $0.9 \mathrm{ml}$ of the brain extract, $150 \mu \mathrm{mol}$ of $\mathrm{KCl}$, $2.5 \mu \mathrm{mol}$ of ATP, $8 \mu \mathrm{mol}$ of $\mathrm{MgCl}_{2}$ and 2.2 $4.4 \mathrm{nmol}(1-2 \mu \mathrm{Ci})$ of $\left[{ }^{14} \mathrm{C}\right]$ tyrosine. After incubation for $20 \mathrm{~min}$ at $37^{\circ} \mathrm{C}$ the mixture was cooled and passed through a column of Sephadex G-25 equilibrated with Pipes buffer to eliminate unbound $\left[{ }^{14} \mathrm{C}\right]$ tyrosine. The excluded material was mixed with 1 vol. of non-labelled brain extract and, after addition of glycerol [40\% (v/v) final concn.], GTP (1 mM) and $\mathrm{MgCl}_{2}(0.5 \mathrm{mM})$, tubulin was allowed to assemble by incubating the mixture at $37^{\circ} \mathrm{C}$ for $30 \mathrm{~min}$. After centrifugation at $100000 \mathrm{~g}$ for $30 \mathrm{~min}$ at $27^{\circ} \mathrm{C}$ the pellet was resuspended in Mes buffer $(0.1 \mathrm{M}$-Mes adjusted with $\mathrm{KOH}$ to pH6.7, containing $1 \mathrm{mM}-\mathrm{EGTA}$ ) to give a protein concentration of about $3 \mathrm{mg} / \mathrm{ml}$. After $30 \mathrm{~min}$ at $0^{\circ} \mathrm{C}$ the suspension was centrifuged at $100000 \mathrm{~g}$ for $10 \mathrm{~min}$ at $2-4^{\circ} \mathrm{C}$. The supernatant solution (microtubule protein purified by one cycle) was designated MTP $(\times 1)$. Subsequent assembly-disassembly cycles were carried out in Mes buffer in the presence of $1 \mathrm{mM}-\mathrm{GTP}$ and $0.5 \mathrm{~mm}-\mathrm{MgCl}_{2}$. The incubation time for assembly was $15 \mathrm{~min}$ and the warm centrifugation to separate the assembled from the non-assembled fraction was at $100000 \mathrm{~g}$ for $10 \mathrm{~min}$. The purified microtubule protein preparations $\operatorname{MTP}(\times 1), \operatorname{MTP}(\times 2)$ and so forth were immediately used: $\times 1, \times 2$, etc. indicate the number of the assembly-disassembly cycles. The post-assembly supernatant fraction obtained after w.arm centrifugations were designated $S_{1}, S_{2}$, etc.

When unlabelled microtubular protein was required, it was obtained as described for the labelled microtubular protein except that the incorporation of $\left[{ }^{14} \mathrm{C}\right]$ tyrosine was omitted.

\section{Measurement of the radioactivity bound to protein}

To an aliquot of the sample to be analysed, $2 \mathrm{ml}$ of $5 \%$ trichloroacetic acid was added; the mixture was heated at $90^{\circ} \mathrm{C}$ for $5 \mathrm{~min}$ and the radioactivity bound to protein was measured in the hottrichloroacetic acid-insoluble material (Barra et al., 1973).

Determination of the release of $\left[{ }^{14} \mathrm{C}\right]$ tyrosine catalysed by the endogenous TTCPase

Unless otherwise specified the $\left[{ }^{14} \mathrm{C}\right]$ tyrosinated MTP preparation was incubated at $37^{\circ} \mathrm{C}$ in the presence of $1 \mathrm{~mm}-\mathrm{GTP}$ and $0.5 \mathrm{~mm}-\mathrm{MgCl}_{2}$. After the stated incubation period the radioactivity bound to protein was measured as described above. The radioactivity release was calculated as the difference between a zero-time control and the experimental tube. All determinations were done in duplicate.

Preparation of pure tubulinyl $\left[{ }^{14} \mathrm{C}\right]$ tyrosine and tubulinyl $\left[{ }^{14} \mathrm{C}\right]$ tyrosine-colchicine complex

A $\left[{ }^{14} \mathrm{C}\right]$ tyrosinated $\mathrm{MTP}(\times 1)$ preparation was obtained as described above except that before the incorporation of $\left[{ }^{14} \mathrm{C}\right]$ tyrosine the brain extract was passed through a column of Sephadex G-25 and that $11 \mathrm{nmol}(5 \mu \mathrm{Ci})$ was the amount of $\left[{ }^{14} \mathrm{C}\right]$ tyrosine added $/ \mathrm{ml}$ of incubation system. Then, the $\left[{ }^{14} \mathrm{C}\right]$ tyrosinated $\mathrm{MTP}(\times 1)$ preparation was chromatographed on a column of phosphocellulose as described by Sloboda \& Rosenbaum (1982) except that Mes buffer was used instead of Pipes. The $\left[{ }^{14} \mathrm{C}\right]$ tyrosinated tubulin collected in the excluded volume was more than $95 \%$ pure as judged by polyacrylamide-gel electrophoresis performed according to Weber \& Osborn (1969). No TTCPase activity was found in this preparation. To obtain the tubulinyl[ $\left[{ }^{14} \mathrm{C}\right]$ tyrosine-colchicine complex, a fraction of the purified $\left[{ }^{14} \mathrm{C}\right]$ tyrosinated tubulin preparation was incubated in the presence of $0.2 \mathrm{mM}$-colchicine for $2 \mathrm{~h}$ at $37^{\circ} \mathrm{C}$ in the darkness and immediately passed through a column of Sephadex G-25 equilibrated with Mes buffer to eliminate unbound colchicine. Both preparations were immediately used.

\section{Purification of TTCPase}

A 400-fold purified preparation of TTCPase was obtained from rat brain as described by Modesti et al. (1984).

\section{Polyacrylamide-gel electrophoresis}

The continuous sodium dodecyl sulphate gel system described by Weber \& Osborn (1969) was used. The gels $(7.5 \%$ acrylamide, $0.097 \%$ bisacrylamide) were $0.8 \mathrm{~cm} \times 10 \mathrm{~cm}$ in size. After running they were stained with Coomassie Brilliant Blue and destained by diffusion. 


\section{Turbidimetric measurements}

Assembly of tubulin was monitored turbidimetrically at $350 \mathrm{~nm}$ in a Shimadzu double-beam spectrophotometer (model UV-150-02). Temperature was maintained at $37^{\circ} \mathrm{C}$ with a circulating water bath. Assembly was initiated by transferring the microtubular protein preparation to the prewarmed cuvettes in the carousel.

\section{Electron microscopy}

Aliquots $(5 \mu \mathrm{l})$ of microtubule solutions were allowed to settle for $20 \mathrm{~s}$ on carbon-coated Formvar grids. The grids were washed successively with 3 drops of water and 3 drops of $1 \%$ uranyl acetate, and the excess uranyl acetate was drawn off with filter paper. Grids were examined after they had been air-dried.

\section{Protein determination}

Proteins were determined by the method of Lowry et al. (1951) using bovine serum albumin as the standard.

\section{Results and discussion}

Detyrosination of tubulinyl $\left[{ }^{14} \mathrm{C}\right]$ tyrosine isolated from the assembled and non-assembled fractions

It is known that in nervous tissue there are several isotypes of tubulin (Gozes \& Littauer, 1978; Marotta et al., 1978; Dahl \& Weibel, 1979). To determine whether the tubulinyl[ $\left.{ }^{14} \mathrm{C}\right]$ tyrosine that remains in the non-assembled fractions is similar to that obtained from disassembled microtubules with respect to its capability to release $\left[{ }^{14} \mathrm{C}\right]$ tyrosine, the following experiment was carried out. $\left[{ }^{14} \mathrm{C}\right]$ Tyrosinated MTP $(\times 2)$ and $\mathrm{S}_{2}$ preparations were mixed with unlabelled $\mathrm{S}_{2}$ and $\operatorname{MTP}(\times 2)$ preparations, respectively, to obtain two systems of similar final composition and then incubated at $37^{\circ} \mathrm{C}$ to determine the release of $\left[{ }^{14} \mathrm{C}\right]-$ tyrosine by the action of the endogenous TTCPase. It should be noted that under these conditions the formation of microtubules was permissible. The release of $\left[{ }^{14} \mathrm{C}\right]$ tyrosine was similar for both mixtures (Fig. 1) indicating that, in this respect, there are no differences between the molecules of tubulinyl $\left[{ }^{14} \mathrm{C}\right]$ tyrosine obtained from the assembled fraction and those from the non-assembled fraction.

\section{Release of $\left[{ }^{14} \mathrm{C}\right]$ tyrosine from assembled and non- assembled tubulinyl $\left[{ }^{14} \mathrm{C}\right]$ tyrosine under steady-state conditions}

The release of $\left[{ }^{14} \mathrm{C}\right]$ tyrosine was carried out in a system in which both assembled and nonassembled tubulinyl $\left[{ }^{14} \mathrm{C}\right]$ tyrosine were present. Assembly was performed by incubating a $\left[{ }^{14} \mathrm{C}\right]-$ tyrosinated MTP $(\times 2)$ preparation in Mes buffer in

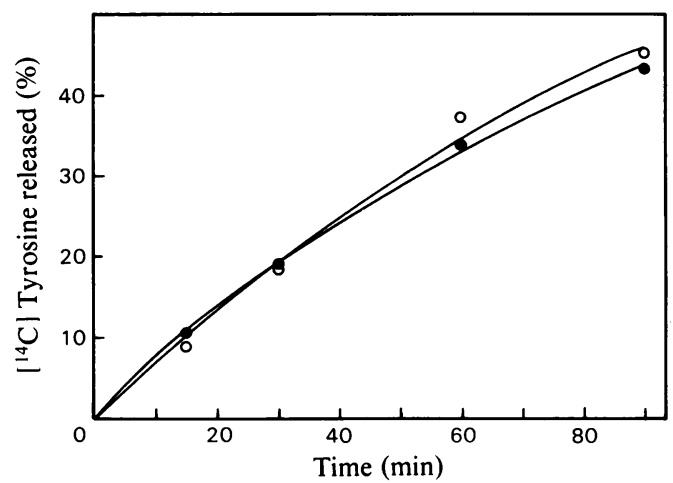

Fig. 1. Release of $\left[{ }^{14} \mathrm{C}\right]$ tyrosine from tubulinyl $\left[{ }^{14} \mathrm{C}\right]$ tyrosine obtained from the assembled and non-assembled fractions

A sample $(2 \mathrm{ml})$ of a $\left[{ }^{14} \mathrm{C}\right]$ tyrosinated $\mathrm{MTP}(\times 1)$ preparation $(3 \mathrm{mg} / \mathrm{ml})$ was processed to obtain the labelled MTP $(\times 2)$ (assembled tubulin) and $S_{2}$ (nonassembled tubulin) fractions. Identical amounts of unlabelled $\operatorname{MTP}(\times 2)$ and $S_{2}$ fractions were also prepared. The total amounts of labelled and unlabelled MTP and $\mathbf{S}$ fractions were mixed as follows: Labelled $\operatorname{MTP}(\times 2)$ plus unlabelled $\mathrm{S}_{2}(\mathrm{O})$ and labelled $S_{2}$ plus unlabelled $\operatorname{MTP}(\times 2)(O)$. The mixtures were incubated at $37^{\circ} \mathrm{C}$ and at the stated times the $\left[{ }^{14} \mathrm{C}\right]$ tyrosine released was measured.

the presence of $1 \mathrm{mM}-\mathrm{GTP}$ and $0.5 \mathrm{mM}-\mathrm{MgCl}_{2}$. The formation of microtubules during the incubation was monitored by turbidimetry and checked by electron microscopy. In our experimental conditions an apparent steady state was reached after $5 \mathrm{~min}$ of incubation. To measure the release of $\left[{ }^{14} \mathrm{C}\right]$ tyrosine in these conditions no addition of TTCPase was necessary since the microtubule protein preparation contains enough enzyme activity (Arce \& Barra, 1983). After different periods of incubation, aliquots $(0.3 \mathrm{ml})$ were removed and centrifuged to separate the assembled and nonassembled fractions. Aliquots removed at 5, 20 and $60 \mathrm{~min}$ of incubation were shown to contain the same proportion (about $75 \%$ ) of assembled protein. The specific radioactivity (c.p.m. bound to protein/mg of protein) was measured in the assembled and non-assembled fractions (Fig. 2). To compare the rate of decay of the specific radioactivity of assembled tubulin with that of non-assembled tubulin, the values were expressed as percentages (Fig. 2, inset). Tubulin in either state of aggregation was detyrosinated at a similar rate. The difference in the specific radioactivity between assembled and non-assembled fractions observed in Fig. 2 is due, in part, to a dissimilar distribution of non-labelled proteins. Polyacrylamide-gel electrophoresis revealed that some microtubuleassociated proteins, such as the high $M_{\mathrm{r}}$ proteins are present only in the assembled fraction (results 


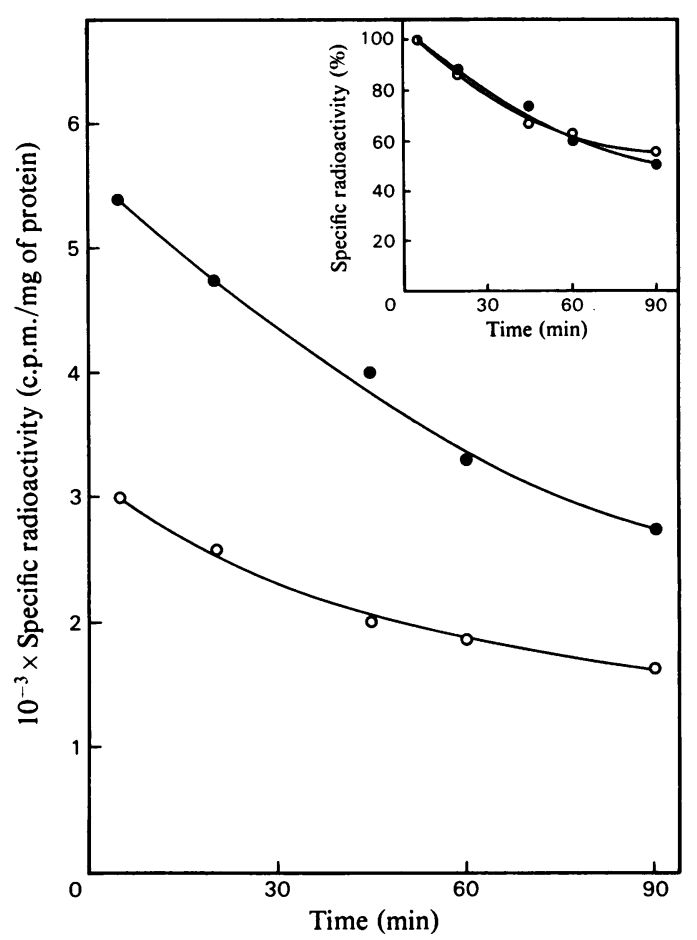

Fig. 2. Detyrosination of assembled and non-assembled tubulin at steady state

A $\left[{ }^{14} \mathrm{C}\right]$ tyrosinated MTP $(\times 2)$ preparation $(3 \mathrm{mg} / \mathrm{ml})$ was incubated in assembly conditions ( $1 \mathrm{mM}-\mathrm{GTP}$, $0.5 \mathrm{mM}-\mathrm{MgCl}_{2}, 37^{\circ} \mathrm{C}$ ) and at the stated times, $0.3 \mathrm{ml}$ aliquots were removed and centrifuged at $100000 \mathrm{~g}$ for $10 \mathrm{~min}$ at $27^{\circ} \mathrm{C}$. The specific radioactivity (c.p.m. bound to protein/mg of protein) was measured in the assembled (O) and non-assembled (O) fractions. Experimental values are the mean of three independent experiments. Inset: values were expressed as percentages with reference to the specific radioactivity at $5 \mathrm{~min}$ of incubation.

not shown). In addition, during the warm centrifugation, $\left[{ }^{14} \mathrm{C}\right]$ tyrosine is released from the pelleted microtubules faster than from the non-assembled tubulin dimers (see below), contributing in this way to the difference in specific radioactivity between both fractions.

\section{Detyrosination of non-assembled tubulin after deple-} tion of microtubules

When microtubules at steady state were eliminated from the incubation system, the nonassembled tubulin fraction was detyrosinated at a very low rate. This result was obtained from the following experiment. A $\left[{ }^{14} \mathrm{C}\right]$ tyrosinated $\operatorname{MTP}(\times 2)$ preparation was incubated at $37^{\circ} \mathrm{C}$ in the assembly conditions described above and after $15 \mathrm{~min}$ the microtubules were spun down. Imme-
Table 1. Release of $\left[{ }^{14} \mathrm{C}\right]$ tyrosine from non-assembled tubulin in a system depleted of microtubules A $\left[{ }^{14} \mathrm{C}\right]$ tyrosinated $\mathrm{MTP}(\times 2)$ preparation was incubated in assembly conditions for $15 \mathrm{~min}$ and microtubules were eliminated by centrifugation. The microtubule-depleted supernatant fraction was further incubated for $60 \mathrm{~min}$ at $37^{\circ} \mathrm{C}$ to measure the release of $\left[{ }^{14} \mathrm{C}\right]$ tyrosine. For comparison, the release of $\left[{ }^{14} \mathrm{C}\right]$ tyrosine from a MTP $(\times 2)$ preparation was also measured. An identical procedure was carried out with $\left[{ }^{14} \mathrm{C}\right]$ tyrosinated MTP $(\times 3)$ and $\operatorname{MTP}(\times 4)$ preparations. Experimental values are the mean for the determinations in three different experiments.

Release of

$\left[{ }^{14} \mathrm{C}\right]$ tyrosine

Preparation

$(\%)$

$\operatorname{MTP}(\times 2)$

Microtubule-depleted MTP $(\times 2)$

$\operatorname{MTP}(\times 3)$

Microtubule-depleted MTP $(\times 3)$

$\operatorname{MTP}(\times 4)$

Microtubule-depleted MTP $(\times 4)$
41

4

39

3

34

4 diately, the supernatant solution containing the non-assembled tubulin fraction was incubated at $37^{\circ} \mathrm{C}$ for $60 \mathrm{~min}$ and the release of $\left[{ }^{14} \mathrm{C}\right]$ tyrosine was measured. A similar procedure was carried out with $\mathrm{MTP}(\times 3)$ and $\mathrm{MTP}(\times 4)$ preparations. In Table 1 the release of $\left[{ }^{14} \mathrm{C}\right]$ tyrosine from the microtubule-depleted fraction can be compared with that corresponding to the complete system (nonassembled tubulin plus microtubules at steady state). In all cases, the release from the nonassembled fraction was about 10 -fold lower than that from the complete system. The rate of release of $\left[{ }^{14} \mathrm{C}\right]$ tyrosine from microtubules in the pelleted form was similar to that from the complete system (results not shown). These results indicate that under steady-state conditions, the non-assembled tubulin pool requires to interact with microtubules to be detyrosinated.

Detyrosination of the non-assembled tubulin pool under steady-state conditions

As mentioned above, non-assembled tubulin requires to interact with microtubules to be detyrosinated. We considered alternative mechanisms by which this interaction can occur. One is by simple collisions between non-assembled dimers and the wall of microtubules. The other one is by assembly of the tubulin dimers into the microtubule ends. In connection with this question the following experiment was carried out. An unlabelled $\operatorname{MTP}(\times 2)$ preparation was allowed to assemble and, after reaching the steady state, a trace of labelled substrate (tubulinyl[ $\left[{ }^{14} \mathrm{C}\right]$ tyrosine or tubulinyl[ $\left[{ }^{14} \mathrm{C}\right]$ tyrosine-colchicine complex) was added and the incubation continued. Aliquots 
were removed after different periods of time and centifuged to separate the assembled and nonassembled fractions. Protein and radioactivity bound to protein were determined in each fraction. As can be seen in Table 2 the proportion of protein in the assembled state measured after addition of the tubulinyl[ $\left.{ }^{14} \mathrm{C}\right]$ tyrosine-colchicine complex was practically the same as that measured when tubulinyl[ $\left.{ }^{14} \mathrm{C}\right]$ tyrosine was the labelled substrate added. However, the distribution of the radioactivity between the assembled and non-assembled

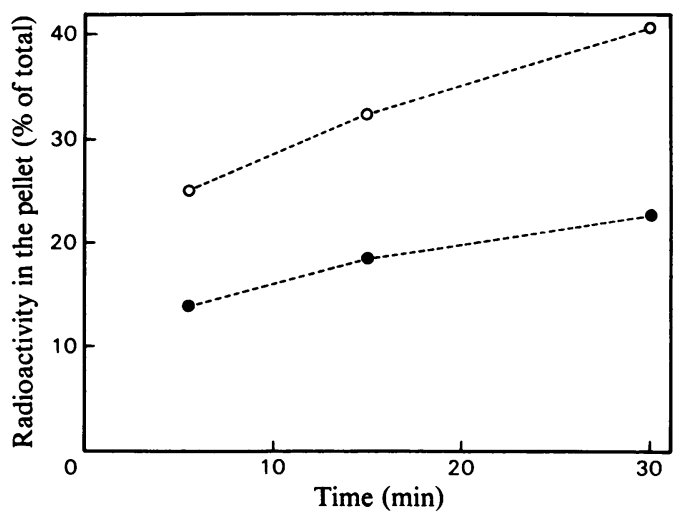

Fig. 3. Distribution of tubulinyl $\left[{ }^{14} \mathrm{C}\right]$ tyrosine and tubulinyl $\left[{ }^{14} C\right]$ tyrosine-colchicine complex between the assembled and non-assembled tubulin fractions

An unlabelled MTP $(\times 2)$ preparation $(3 \mathrm{mg} / \mathrm{ml})$ was incubated in assembly conditions and after $15 \mathrm{~min}$ an aliquot ( $5 \%$ of final volume) of pure tubulinyl$\left[{ }^{14} \mathrm{C}\right]$ tyrosine $(0.95 \mathrm{mg} / \mathrm{ml})(\mathrm{O})$ or tubulinyl $\left[{ }^{14} \mathrm{C}\right]-$ tyrosine-colchicine complex $(0.87 \mathrm{mg} / \mathrm{ml})(O)$ was added and the incubation continued. Aliquots $(0.3 \mathrm{ml})$ were removed at the stated times and centrifuged to separate the assembled and non-assembled fractions. Protein and radioactivity bound to protein were determined. Radioactivity in the pellet was expressed as the percentage with respect to total (radioactivity in the pellet plus that in the supernatant). fractions were dissimilar (Fig. 3). The proportion of radioactivity found in the microtubular fraction was lower when tubulinyl[ $\left.{ }^{14} \mathrm{C}\right]$ tyrosine-colchicine complex was the labelled substrate, indicating that this complex has a diminished ability to assemble into microtubules in comparison with tubulinyl$\left[{ }^{14} \mathrm{C}\right]$ tyrosine. Under these conditions the release of $\left[{ }^{14} \mathrm{C}\right]$ tyrosine from tubulinyl $\left[{ }^{14} \mathrm{C}\right]$ tyrosinecolchicine was lower than that from tubulinyl $\left[{ }^{14} \mathrm{C}\right]-$ tyrosine (Fig. 4). The possibility that this result was due to a lower ability of tubulinyl[ $\left[{ }^{14} \mathrm{C}\right]$ tyrosinecolchicine complex to act as substrate of TTCPase was ruled out, since both tubulinyl[ $\left[{ }^{14} \mathrm{C}\right]$ tyrosine and tubulinyl[ $\left[{ }^{14} \mathrm{C}\right]$ tyrosine-colchicine complex

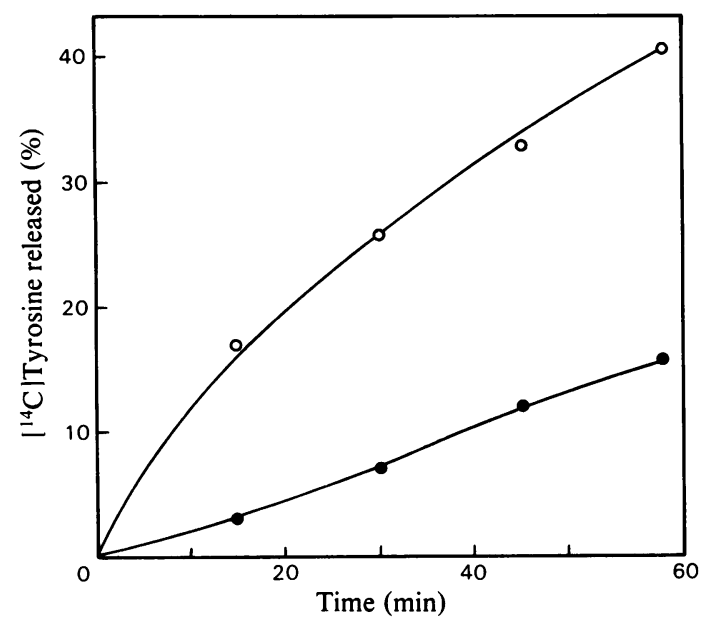

Fig. 4. Release of $\left[{ }^{14} \mathrm{C}\right]$ tyrosine after addition of tubulinyl $\left[{ }^{14} \mathrm{C}\right]$ tyrosine $(\mathrm{O})$ or tubulinyl $\left[{ }^{14} \mathrm{C}\right]$ tyrosine-colchicine complex (O) to a preparation of microtubules at steady state Protocol and experimental conditions were identical to those described in Fig. 3 except that after addition of the labelled substrates, aliquots $(50 \mu \mathrm{l})$ were removed at the stated times to measure the $\left[{ }^{14} \mathrm{C}\right]$ tyrosine released as described in the Materials and methods section.

Table 2. Distribution of protein between the assembled and non-assembled fractions Protocol and experimental conditions were those described in Fig. 3.

\begin{tabular}{cccc} 
& & \multicolumn{2}{c}{ Protein (mg) in: } \\
\cline { 3 - 4 } Addition & $\begin{array}{c}\text { Incubation } \\
\text { time (min) }\end{array}$ & $\begin{array}{c}\text { Assembled } \\
\text { fraction }\end{array}$ & $\begin{array}{c}\text { Non-assembled } \\
\text { fraction }\end{array}$ \\
\hline Tubulinyl[ ${ }^{14}$ C]tyrosine & 5 & 0.61 & 0.29 \\
& 25 & 0.66 & 0.27 \\
Tubulinyl[ $\left.{ }^{14} \mathrm{C}\right]-$ & 45 & 0.65 & 0.22 \\
tyrosine-colchicine & 5 & 0.58 & 0.31 \\
& 25 & 0.62 & 0.27 \\
& 45 & 0.61 & 0.26
\end{tabular}


were shown to be detyrosinated at the same rate when tested with exogenous enzyme in an incubation system where no microtubules are formed (Fig. 5a). In addition, the presence of free colchicine in the incubation system did not affect the activity of the enzyme (Fig. $5 b$ ). Therefore, the decrease in the rate of detyrosination observed when the capability of the radioactive substrate to assemble into microtubules was diminished supports the idea that the detyrosination of the nonassembled tubulin pool occurs via assembly into microtubules. If the release of $\left[{ }^{14} \mathrm{C}\right]$ tyrosine from the non-assembled tubulin pool occurred via simple collisions with the microtubule walls, the rate of release of $\left[{ }^{14} \mathrm{C}\right]$ tyrosine should be the same

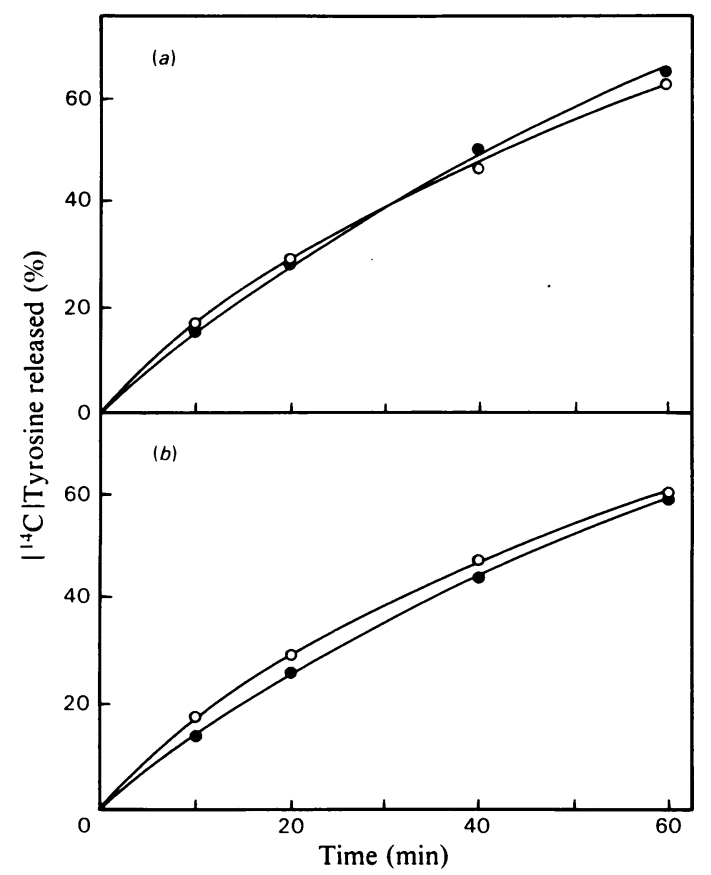

Fig. 5. Effect of colchicine on the release of $\left[{ }^{14} \mathrm{C}\right]$ tyrosine from pure tubulinyl $\left[{ }^{14} \mathrm{C}\right]$ tyrosine

(a) Effect of colchicine bound to tubulin. Tubulinyl$\left[{ }^{14} \mathrm{C}\right]$ tyrosine $(\mathrm{O})(20 \mu \mathrm{g}, 12000 \mathrm{c}$.p.m. $)$ or tubulinyl[ $\left.{ }^{14} \mathrm{C}\right]$ tyrosine-colchicine complex $(\Theta)(18 \mu \mathrm{g}$, 11000 c.p.m.) and TTCPase (10 $\mu \mathrm{g})$ were incubated at $37^{\circ} \mathrm{C}$ in a system containing $100 \mathrm{~mm}$-Mes buffer, $\mathrm{pH}$ 6.7, $1 \mathrm{~mm}-\mathrm{GTP}$ and $2 \mathrm{~mm}-\mathrm{MgCl}_{2}$. Final volume, $0.1 \mathrm{ml}$. (b) Effect of free colchicine. Tubulinyl[ $\left.{ }^{14} \mathrm{C}\right]-$ tyrosine $(20 \mu \mathrm{g}, 12000 \mathrm{c} . \mathrm{p} . \mathrm{m}$.$) and TTCPase (10 \mu \mathrm{g})$ were incubated at $37^{\circ} \mathrm{C}$ in a system containing $100 \mathrm{~mm}$-Mes buffer, pH6.7, $1 \mathrm{~mm}$-GTP and $2 \mathrm{~mm}$ $\mathrm{MgCl}_{2}$ in the absence $(\mathrm{O})$ or in the presence $(O)$ of $0.1 \mathrm{~mm}$-colchicine. Final volume, $0.1 \mathrm{ml}$. At the stated times the radioactivity bound to protein was measured and the $\left[{ }^{14} \mathrm{C}\right]$ tyrosine released was expressed as the percentage with respect to a zero-time control. whatever the distribution of the labelled substrate between the assembled and non-assembled fractions.

Since the intrinsic capability of the tubulin molecule to be detyrosinated is not altered by the binding of colchicine, the use of this drug allowed us to estimate the relative capabilities of assembled and non-assembled tubulin to act as substrates of TTCPase. The release of $\left[{ }^{14} \mathrm{C}\right]$ tyrosine from a $\left[{ }^{14} \mathrm{C}\right]$ tyrosinated $\mathrm{MTP}(\times 2)$ preparation was measured in the absence or presence of $0.1 \mathrm{mM}$ colchicine. From results in Fig. 6 it can be inferred that the release from microtubules is at least 2.5fold faster than that from non-assembled tubulin.

Effect of increasing TTCPase concentrations on the release of tyrosine from tubulin and microtubules at steady state

Considering our results, the detyrosination of assembled and non-assembled tubulin at steady state by the action of the endogenous TTCPase would be as follows. TTCPase is mostly associated with microtubules and catalyses the release of tyrosine from the assembled tubulin. The nonassembled tubulin pool is only detyrosinated after assembly into microtubules. The finding of similar rates of detyrosination for the assembled and nonassembled tubulin pools (Fig. 2) implies that the exchange of tubulin dimers between tubulin and microtubules should be very rapid in comparison with the rate of detyrosination. If the rate of

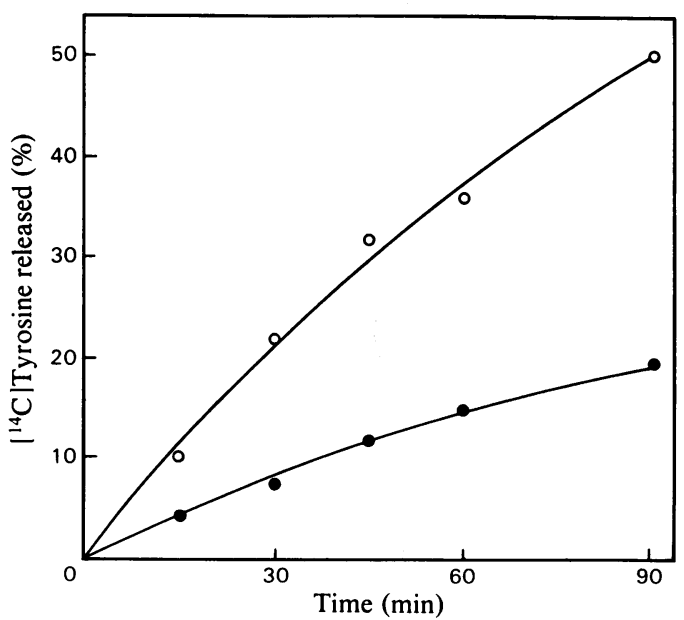

Fig. 6. Effect of colchicine on the release of $\left[{ }^{14} \mathrm{C}\right]$ tyrosine from $a\left[{ }^{14} \mathrm{C}\right]$ tyrosinated microtubule protein preparation A $\left[{ }^{14} \mathrm{C}\right]$ tyrosinated $\mathrm{MTP}(\times 2)$ preparation $(3 \mathrm{mg} / \mathrm{ml})$ was incubated in assembly conditions in the absence $(O)$ or in the presence (O) of $0.1 \mathrm{~mm}$-colchicine. At the stated times the $\left[{ }^{14} \mathrm{C}\right]$ tyrosine released was determined as described in the Materials and methods section. 
Table 3. Effect of increasing TTCPase concentrations on the release of tyrosine from tubulin and microtubules at steady state

A $\left[{ }^{14} \mathrm{C}\right]$ tyrosinated $\mathrm{MTP}(\times 2)$ preparation $(2.5 \mathrm{mg} / \mathrm{ml})$ was incubated in assembly conditions in the presence of purified TTCPase at the indicated concentrations. After 5 and $20 \mathrm{~min}$ of incubation, $0.3 \mathrm{ml}$ aliquots were removed and centrifuged at $100000 \mathrm{~g}$ for $10 \mathrm{~min}$ at $27^{\circ} \mathrm{C}$. The specific radioactivity (c.p.m. bound to protein $/ \mathrm{mg}$ of protein) was measured in the assembled and non-assembled fractions. The decay of the specific radioactivity from 5 to $20 \mathrm{~min}$ of incubation indicated the release of $\left[{ }^{14} \mathrm{C}\right]$ tyrosine that occurred during the $15 \mathrm{~min}$ interval.

\begin{tabular}{ccc} 
& \multicolumn{3}{c}{$\left[{ }^{14} \mathrm{C}\right]$ Tyrosine released $(\%)$} \\
\cline { 2 - 3 } Added TTCPase $(\mathrm{mg} / \mathrm{ml})$ & Tubulin & Microtubules \\
\hline 0 & 15 & 14 \\
0.06 & 15 & 18 \\
0.18 & 18 & 38 \\
0.36 & 21 & 49
\end{tabular}

detyrosination were higher than that of exchange, microtubules should be more detyrosinated than non-assembled tubulin. This hypothesis was confirmed by measuring the release of $\left[{ }^{14} \mathrm{C}\right]$ tyrosine at increasing concentrations of TTCPase relative to the MTP concentration. Results from a typical experiment are shown in Table 3.

These results taken together indicate that the tyrosination state of tubulin and microtubules depends not only on the relative capabilities of both states of aggregation to act as substrates of TTCPase but also on the rate of exchange of tubulin dimers. In addition, since TTCPase appears to act almost exclusively on microtubules and TTLase on non-assembled tubulin (Arce et al., 1978; Deanin et al., 1980; Kumar \& Flavin, 1981), it becomes evident that the turnover of the $C$ terminal tyrosine is dependent upon assembly-disassembly of tubulin. This is compatible with a previous report by Thompson et al. (1979) who found in living cells in culture that intact microtubules are required for rapid turnover of the $C$ terminal tyrosine.
We are grateful to Dr. R. Caputto, Dr. J. A. Curtino and Ing. M. A. Aón for critical review of the manuscript. This work was supported in part by grants from the Consejo Nacional de Investigaciones Científicas y Técnicas, the Subsecretaría de Ciencia y Tecnología and the Consejo de Investigaciones Científicas y Tecnológicas de la Provincia de Córdoba, Argentina.

\section{References}

Arce, C. A. \& Barra, H. S. (1983) FEBS Lett. 157, 75-78

Arce, C. A., Rodriguez, J. A., Barra, H. S. \& Caputto, R. (1975) Eur. J. Biochem. 59, 145-149

Arce, C. A., Hallak, M. E., Rodriguez, J. A., Barra, H. S. \& Caputto, R. (1978) J. Neurochem. 31, 205-210

Argaraña, C. E., Barra, H. S. \& Caputto, R. (1980) J. Neurochem. 34, 114-118

Barra, H. S., Rodriguez, J. A., Arce, C. A. \& Caputto, R. (1973) J. Neurochem. 20, 97-108

Barra, H. S., Arce, C. A., Rodriguez, J. A. \& Caputto, R. (1974) Biochem. Biophys. Res. Commun. 60, 1384-1390

Dahl, J. L. \& Weibel, V. J. (1979) Biochem. Biophys. Res. Commun. 86, 822-828

Deanin, G. G., Preston, S. F., Hanson, R. K. \& Gordon, M. W. (1980) Eur. J. Biochem. 109, 207-216

Gozes, I. \& Littauer, U. Z. (1978) Nature (London) 276, 411-413

Hallak, M. E., Rodriguez, J. A., Barra, H. S. \& Caputto, R. (1977) FEBS Lett. 73, 147-150

Kumar, N. \& Flavin, M. (1981) J. Biol. Chem. 256, 76787686

Kumar, N. \& Flavin, M. (1982) Eur. J. Biochem. 128, 215-222

Lowry, O. H., Rosebrough, N. J., Farr, A. L. \& Randall, R. J. (1951) J. Biol. Chem. 193, 265-275

Marotta, C. A., Harris, J. L. \& Gilbert, J. M. (1978) J. Neurochem. 30, 1431-1440

Modesti, N. M., Argaraña, C. E., Barra, H. S. \& Caputto, R. (1984) J. Neurosci. Res., in the press

Raybin, D. \& Flavin, M. (1977) Biochemistry 16, 2189 2194

Rodriguez, J. A. \& Borisy, G. G. (1979) Biochem. Biophys. Res. Commun. 89, 893-899

Sloboda, R. D. \& Rosenbaum, J. L. (1982) Methods Enzymol. 85, 409-416

Thompson, W. C. (1977) FEBS Lett. 80, 9-13

Thompson, W. C., Deanin, G. G. \& Gordon, M. W. (1979) Proc. Natl. Acad. Sci. U.S.A. 76, 1318-1322

Weber, K. \& Osborn, M. (1969) J. Biol. Chem. 244, 44064412 